\title{
The Ancient Legend about Surt and the Novel Concept of Methane Venting Tectonics (MTV)
}

\author{
Nils-Axel Mörner1', Ciara Duffy² \\ ${ }^{1}$ Paleogeophysics \& Geodynamics, Stockholm, Sweden \\ ${ }^{2}$ Point Cook, Victoria, Australia \\ Email: morner@pog.nu
}

How to cite this paper: Mörner, N.-A., \& Duffy, C. (2020). The Ancient Legend about Surt and the Novel Concept of Methane Venting Tectonics (MTV). Archaeological Discovery, 8, 288-294.

https://doi.org/10.4236/ad.2020.83016

Received: June 24, 2020

Accepted: July 13, 2020

Published: July 16, 2020

Copyright $\odot 2020$ by author(s) and Scientific Research Publishing Inc. This work is licensed under the Creative Commons Attribution International License (CC BY 4.0).

http://creativecommons.org/licenses/by/4.0/

\begin{abstract}
We merge the concept of methane venting tectonics and the old legend about Surt, the giant of fire, living in the underground and having a burning sword. Due to the tumbling and collisions between blocks thrown up in the air by the explosive methane venting forces, ignition is likely to have set the methane on fire; i.e. huge burning columns of tens to hundreds of metres height. Such events occurred in east-central Sweden at about 3000 BP. The Bronze Age people are likely to have understood it as Surt pushing up his sword of fire from the underground. The legends of Surt, the Fenris Wolf, the Midgårds Serpent and the Ragnarök apocalypse, all seem to owe their origins to the violent geodynamic activity along the east-central part of Sweden at about 3000 BP. We may therefore speak about an ancient "Svenonian mythology", which precedes the Norse mythology of the Edda by about 2000 years.
\end{abstract}

\section{Keywords}

Nordic Mythology, Surt the Giant of Fire in the Underground, Methane

Venting Tectonics, The Fenris Wolf, Ground Shaking, The Ragnarök

Apocalypse, The 3000 BP Events

\section{Introduction}

Explosive methane venting in the crystalline bedrock was first reported by Mörner (2003) and further discussed in subsequent papers (Mörner, 2011, 2013) Because the explosive methane venting leads to extensive bedrock deformation, the process became known as Methane Venting Tectonics (abbreviated MVT). The first general presentation of the concept of Methane Venting Tectonics came in 2017 (Mörner, 2017a, 2017b). So far, the work of the first author (NAM).

The second author (CD) happened to come across the presentation of the 
MVT concept (Mörner, 2017a), and made an intuitive association with the action of the giant Surt in Nordic mythology. This led to the present study: the merging of the two concepts.

\section{Methane Venting Tectonics}

Methane can occur in two stages in nature; as methane gas and as methane hydrate (also termed methane ice because it is a solid). The stage is defined by temperature and pressure, and the boundary between the two stages is a phase boundary. The volumetric change from hydrate to gas is as 1:168 (room temperature conditions), which implies that a sudden change from methane hydrate in the subsurface to methane gas may generate explosive venting.

The conditions for accumulation of methane hydrate in crystalline bedrock in Sweden are: 1) methane degassing (measured in drill-holes, (Mörner, 2011, 2017a) and observed as carbonate precipitates in the varved clay (Mörner, 2003, 2017b), 2) pre-existing fractures and voids in the rock (well recorded), 3) presence of water (in the fractures and voids), 4) a geothermal gradient allowing the formation of methane hydrate (Figure 1a in Mörner, 2017a) and 5) major changes in temperature and pressure in association with the waxing and waning of ice caps of the Quaternary Ice Ages (Figure 1b in Mörner, 2017a). The sudden transformation from solid methane hydrate (ice) to methane gas at a very much increased volume forcing the gas to vent can be triggered by long-term changes in temperature and pressure (glacial isostatic uplift) or by sudden pressure impulses from earthquakes Mörner, 2003; Figure 3 in Mörner, 2017a).

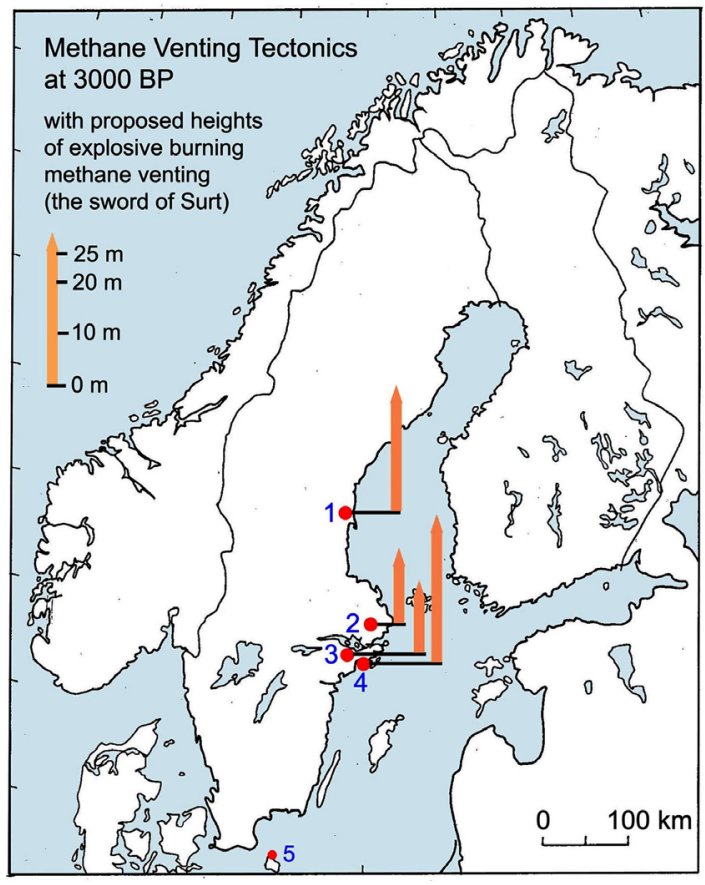

Figure 1. Site of methane venting tectonics at about 3000 BP (i.e. in the middle of the Bronze Age) with minimum estimate of the height of the corresponding venting gas columns. Heights of the flames may be up to 10 times higher, however. 
Mörner (p. 106 in Mörner, 2003, Figure 7 in Mörner, 2017a, Mörner, 2016a) presented a model of methane venting tectonics, which illustrate the underground phase transition and the explosive gas venting forcing huge bedrock blocks to be thrown up into a 20 - $25 \mathrm{~m}$ high cone of detached blocks. There are also cases when the old glacially polished bedrock surface has been fractured into loose dislocated blocks moved or thrown out of position due to ground shaking and/or methane venting tectonics.

Methane venting tectonics (MVT) occurred frequently during the deglaciation period when isostatic uplift changed the underground pressure and when paleoseismic activity was strong both in magnitude and frequency. Ten sites are described from Sweden and two from Finland from the deglacial time (Mörner, 2017a, 2017b). Four additional sites date from about 3000 BP (Figure 1), however, and will be discussed below.

Site 1 (Skålboberget) refers to a $20 \mathrm{~m}$ high cone of angular block torn out of the original bedrock position (Mörner, 2003, 2017a, 2017b). The largest blocks (on the order of hundreds of tons) are at the top of the cone. The venting of methane is recorded in the incorporation of dead carbon in the C14-dates, and ${ }^{13} \mathrm{C}$ values indicating anaerobic oxidation of methane and iron sulphide reduction (Mörner, 2017a). The deformation generated a tsunami wave of a height of about $12 \mathrm{~m}$ (Mörner, 2016b).

Site 2 (Tolan in Upplands-Väsby) refers to a heavily deformed glacially polished surface in glacially stoss-side position. Huge bedrock blocks were torn loose and thrown up to $50 \mathrm{~m}$ away, landing on former beach material from the time of emergence at about $5000 \mathrm{BP}$. The area seems struck both by seismic ground shaking and methane venting tectonics. Besides, a high-amplitude tsunami wave invaded a nearby lake basin at about 3000 BP. When this site was investigated in 2018-2019, it occurred to one of us (NAM) that the blocks thrown 40 - 50 m away, must have generated sparks when landing on other blocks, and those sparks might have ignited the methane gas. If so, the burning methane would have taken the form of light columns coming out of the ground. So, when the second author (CR) proposed the action of Surt, things fell together that the burning methane column might be the burning sword of Surt. Many stones at this site are scorched by fire. But it is impossible to know if this originates from burning methane venting or from later action by people.

Site 3 (Marviken) refers to a fracture valley where faulting, earth sliding, methane venting and a tsunami were recorded and dated at about $3000 \mathrm{BP}$ (Mörner, 2003, 2009, 2017a; Mörner \& Strandberg, 2009). Methane venting tectonics was documented at 3 separate points (Figure 5 in Mörner, 2017a). The valley sides are full of fracture marks and angular blocks (even a Bronze Age grave mound was deformed). Therefore, it seems quite relevant that the origin of the word "Marviken" originates from "mardher", an ancient name for "fractured" going back to the late Bronze Age (Mörner \& Strandberg, 2009).

Site 4 (Kvarnberget) refers to a $25 \mathrm{~m}$ high cone of huge angular blocks with 
gigantic blocks at the top (Mörner, 2017a, 2017b; Mörner \& Sjöberg, 2011). The shape, size and block organization was found (Figure 6 in Mörner, 2017a) to indicate "very strong venting forces concentrated to a venting tube (or chimney)". The deformation is linked to a huge delta at $+15 \mathrm{~m}$ (p. 25 in Mörner, 2017b), which implies an age of about $3000 \mathrm{BP}$.

\section{Surt: The Giant of Fire}

In the Nordic mythology, Surt was a giant and the ruler of fire (Figure 2). He lived in the underground together with the other giants of fire. He had a sword of fire, shining stronger than the Sun and being superior to all other weapons. At the doomsday Ragnarök, Surt lead the giants of fire against the gods in Asgard.

The Sun and the Moon were devoured by wolves, the Fenris Wolf escaped from his chains within the mountains, and the giant Midgard Serpent appeared in the sea. The stars fell, the ground trembled violently from earthquakes and the bedrock fractured into pieces-this was Ragnarök, the end of the World.

In the battle between the Gods and the giants and monsters, Surt swings his sword that shines and sparks long distances.

According to Simek (2007), this legend is ancient, but became included in the Norse mythology, when Iceland was settled by Norwegian Vikings and they experienced volcanism for the first time. Therefore, not until the discovery of explosive methane venting tectonics in Sweden (Mörner, 2003) was there any reasons to propose the interpretation here presented. The high paleoseismic activity recorded in the Late Holocene (Mörner, 2003, 2009), however, lead to the proposal that the legend of the Fenris Wolf, in fact, originated from about $3000 \mathrm{BP}$ (Mörner, 2007).

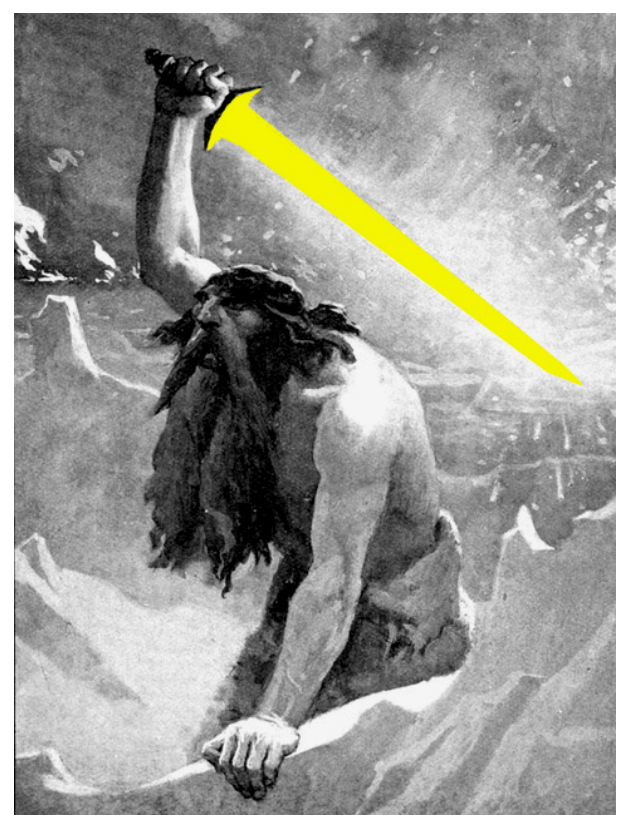

Figure 2. The giant Surt of the underground with his gigantic sword of fire (modified from classical illustration by J. C. Dollman). 


\section{Merging the Concept of Methane Venting Tectonics and the Legend of Surt}

The concept of methane venting tectonics is young; proposed in 2003 (Mörner, 2003) and presented as operating process in 2017 (Mörner, 2017a). The legend of Surt is old. According to the Icelandic Edda (Sturlasson, 1220) it is a part of the Asa Creed held by the Vikings.

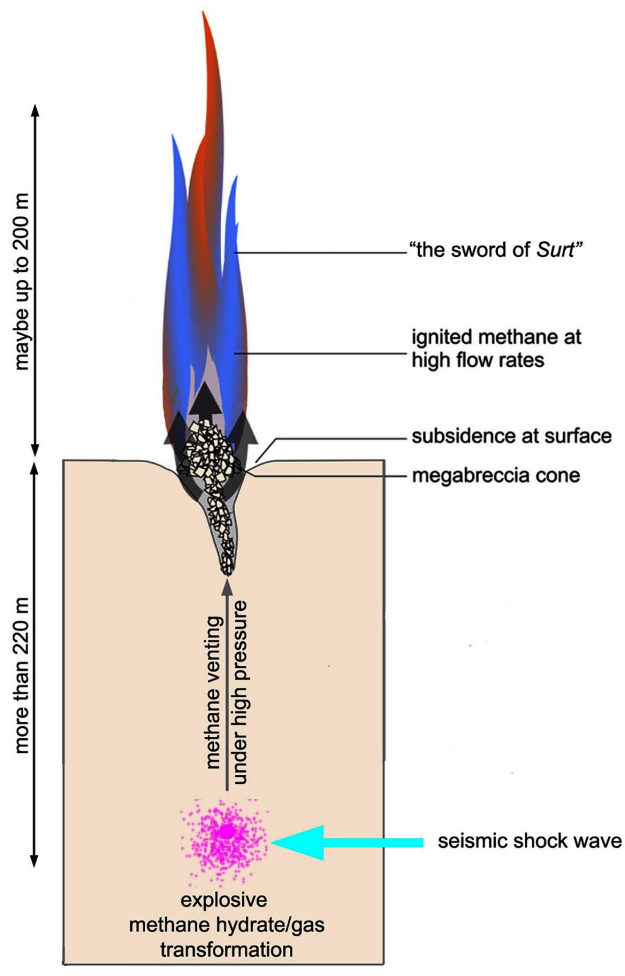

Figure 3. Schematic illustration of the concept of methane venting tectonics (Sites 1 - 4), and the proposed burning flames of methane gas reaching high up in the air, by the locals understood in terms of Surt pushing up his sword of fire from the underground.

According to others (Simek, 2007; Mörner, 2007; Scott Littleton, 1964) certain parts of the proposed Asa Creed may, in fact, be much older. The legend about the Fenris Wolf (shaking the mountains so that they fracture and collapse) has been ascribed to the violent seismo-tectonics recorded in the Bronze Age (Mörner, 2007). The Midgård Serpent occurs on a rock-carving from the Bronze Age (point 5 in Figure 1) and must hence have a similar age (Mörner, 2020). The legend about the end of the World (Ragnarök) seems to fit perfectly well with the violent seismo-tectonics and methane venting tectonics observed at about 3000 BP (Mörner, 2020). We now propose that the legend of Surt should have a similar age and origin.

Surt was the leading fire-giant living in the underground. His sword was made of fire. It was huge and frightening, and shining over long distances.

The methane venting at methane venting tectonics events implied "very 
strong venting forces concentrated to a venting tube (or chimney)". When burning (due to stone-to-stone sparking), the columns (tubes or chimneys) must have exceeded the cones high up in the sky like gigantic swords from the underground; a magnificent view but also a most frightening view (Figure 3). The interpretation of a giant pushing up his burning sword from the underground seems very close and logical. This is our proposal, and it implies that even the legend of Surt emanates from actual earth processes dating back to about 3000 BP.

\section{Conclusion}

The legend of the giant Surt with his burning sword has an origin far older than the Norse mythology of Viking time. We demonstrate that it originates from the mid Bronze Age when violent methane venting tectonics occurred in east-central Sweden at about $3000 \mathrm{BP}$.

When the huge pillar of explosive methane venting in flames emerged out of the ground, it was understood in terms of a giant (which of course must be Surt) sticking up his burning sword from the underground.

This means that the legend of Surt becomes 2000 years older than generally assumed. But he is not alone; the Fenris Wolf (Mörner, 2007), the Midgård Serpent (Mörner, 2020) and the idea of Ragnarök (Mörner, 2007, 2020) are already there.

Even if there might be similarities in old Indo-European mythology, what we are talking about all go back to local people's personal observations in the field of events that occurred at $3000 \mathrm{BP}$ in east-central Sweden, or what we generally call "Svealand" (termed "Svenonian" by Tacitus, AD 79, and "Svitjod" in Icelandic sagas).

Therefore, it seems, we have to start speaking about "the Svenonian Mythol$o g y$ " originating in the violent geodynamic processes in the mid Bronze Age at about $3000 \mathrm{BP}$.

By merging the legend of Surt with the concept of methane venting tectonics, the idea that the tumbling of stones and block at the explosive venting may have ignited the methane gas has become strongly supported; as illustrated in Figure 3.

\section{Acknowledgements}

We are indebted to Brendan Duffy for insisting on high flames into the sky as illustrated in Figure 3, the upper part of which was drawn by him. We acknowledge constructive linguistic check by Dr. Pamela Matlack-Klein. We declare no competing interest and no funding to declare.

\section{Conflicts of Interest}

The authors declare no conflicts of interest regarding the publication of this paper.

\section{References}

Mörner, N.-A. (2003). Paleoseismicity of Sweden-A Novel Paradigm. 16th International 
INQUA Congress, Reno, Nevada, 1-320.

Mörner, N.-A. (2007). The Fenris Wolf in the Nordic Asa Creed in the Light of Paleoseismics. Geological Society, London, Special Publications, 273, 117-119. https://doi.org/10.1144/GSL.SP.2007.273.01.10

Mörner, N.-A. (2009). Late Holocene Earthquake Geology in Sweden. Geological Society, London, Special Publications, 316, 179-188. https://doi.org/10.1144/SP316.11

Mörner, N.-A. (2011). Plaeoseismology: The Application of Multiple Parameters in Four Case Studies in Sweden. Quaternary International, 242, 65-75. https://doi.org/10.1016/j.quaint.2011.03.054

Mörner, N.-A. (2013). Patterns in Seismology and Palaeoseismology, and Their Application in Long-Term Hazard Assessments-The Swedish Case in View of Nuclear Waste Management. Pattern Recognition in Physics, 1, 75-89. https://doi.org/10.5194/prp-1-75-2013

Mörner, N.-A. (2016a). Methane Venting and Methane Venting Tectonics. 13th International Conference on Gas in Marine Sediments (GIMS13), Tromsø, 19-22 September 2016, Abstracts. https://www.researchgate.net/publication/308306076

Mörner, N.-A. (2016b). Tsunamis in Sweden: Occurrence and Characteristics. In M. Mokhtari (Ed.), Tsunami (Chap. 6, pp. 115-133). London: InTech. https://doi.org/10.5772/63956

Mörner, N.-A. (2017a). Methane Hydrate in Crystalline Bedrock and Explosive Methane Venting Tectonics. Earth-Science Reviews, 169, 202-212. https://doi.org/10.1016/j.earscirev.2017.05.003

Mörner, N.-A. (2017b). Methane Hydrate in Crystalline Bedrock and Explosive Methane Venting Tectonics. Earth-Science Reviews, 169, 202-212. https://doi.org/10.1016/j.earscirev.2017.05.003

Mörner, N.-A. (2020). The Kaali Impact, Coincidental Deformations and Tsunamis, and Ancient Legends. 10th International INQUA Meeting on Paleoseismology, Active Tectonics and Archeoseismology (PATA), Hornitos, Chile, 8-12 November 2020, Extended Abstracts, 1-4. (In press)

Mörner, N.-A., \& Sjöberg, R. (2011). Excursion Guide. The 2nd International Conference on Granite Caves, Sweden, June 2011, Speleo Publication 12, 28 p.

Mörner, N.-A., \& Strandberg, S. (2009). Marviken. Geologiskt baserad namntolkning. Saga och Sed, Kungl. Gustav Adolfs Akademiens Årsbok 2009, 179-184.

Scott Littleton, C. (1964). The Comparative Indo-European Mythology of George Dumézil. Journal of Folklore Institute, 1, 147-166. https://doi.org/10.2307/3813900

Simek, R. (2007). Dictionary of Northern Mythology. Woodbridge, England: Boydell \& Brewer.

Sturlasson, S. (1220). Den Prosaiska Eddan (Snorre's Edda): Codex Upsaliensis, DG 11. Den Poetiska Eddan. Codex Regius, Det Kongl. Bibl. Köpenhavn. 